and J. Moyle (Edinburgh) have found the specificity and kinetics of phosphate transport in Staphylococcus aureus to resemble those for enzyme-linked reactions, and suggested that the enzyme-substrate complex forms the carrier for the facilitated diffusion. In the closing paper, R. D. Keynes and R. H. Adrian (Cambridge) deseribed how in resting nerve or muscle the membrane is 25-100 times more permeable to potassium ion than sodium ion, the inside of the fibre being negative to the outside. As the action potential ariives, the membrane changes so that sodium ion becomes the more permeable ion, the inside of the fibre now becoming positive. There is no model to date which will account for the observation that the ratio of the permeability of sodium ion to that of potassium ion is linked to the electrical polarization of the adjacent membrane.

There was a lively discussion on many of the papers, and a number of contributors sought to show how ion-exchange systems can lead to a selective action on different cations. On the whole, it seemed that there is still something of a gap between the achievements of the physical chemist and the needs of the biologist with his complex systems; but it seems clear that this general discussion, and the published account which will appear in due course, should do much towards the further closing of this gap in the future. It is clear that the Faraday Society continues to provide a unique forum for the development of the border-line sciences.

\section{D. Euey}

\section{ROYAL COMMISSION ON AWARDS TO INVENTORS}

\section{FINAL REFORT}

T HE fourth and final report of the Royal Commission on Awards to Inventors* concludes the record of the Commission's work. Besides listing decisions of the Commission since November 9,1952 , it discusses certain aspects of the more important of the 115 claims considered since the issue of the previous report. Only nine claims were dealt with under Head 1 of the Warrant during the period, and the Commission from the outset indicated its reluctance to deal with patent claims where the validity of the patent was seriously challenged. Several claims have consequently been referred to the Courts and other claimants have elected to have their claims considered under Head 3, that is, under the exercise of the Crown's bounty in granting an ex gratia award. By far the majority of claims heard by the Commission have been brought by such claimants, who have waived, or have not possessed, legal rights to support their claims. This procedure cannot be applied to claimants possessing patent rights who, after the period to which their claim relates, have assigned their patents to a third party. Normally, at the request of the Crown, the Commission has taken into account, in estimating the utility of the invention, its possible future use by the Crown as well as the past use. In a claim by J. R. Geigy S.A. and the Geigy Co., Ltd., relating to dichlorodiphenyltrichloroethane, the patents covering the invention had; at the date of hearing, been transferred to a

* Royal Commission on Awards to Inventors-Fourth and Final newly formed company which was not a party to the claim, and the claimants undertook either to amend the claim by joining the patentees or to obtain an undertaking safeguarding the Crown from any further claim.

From time to time it has been urged on the Commission that exceptionally large use of an invention should be taken not merely as an important factoi but as the predominant factor in determining the quantum of an award. It was on this principle that, in view of evidence showing the highly effective use of rockets in the later stage of the War, both in regard to material and to morale, the Commission, notwithstanding the heavy discount which the status of the claimants involved, recommended an award of $£ 5,000$ for the invention of a loose-charge rocket motor. In regard to novelty and originality of invention, the material question which has weighed with the Commission has been whether it has been the earlier or later publication or communication which has in fact led to the practical use of the invention by the Crown; nor has the fact that the claimant has patented his invention abroad, and thereby knowledge of the invention has been made available to an enemy country, necessarily disqualified the claimant from receiving an ex gratia award. Accordingly, the Swiss firm of J. R. Geigy S.A. was not disqualified from receiving an award in respect of the exceptional usefulness of DDT as a means of safeguarding the health of British troops; in the same way, notwithstanding the fact that the information contained in the late Prof. N. A. V. Piercy's earlier papers dealing with the mathematical basis of the design of aerofoil sections had become common knowledge among aeroplane constructors, the Commission, in view of evidence that his subsequen's confidential communications to the Air Ministry were of permanent value for the constiuction of aerofoils, recommended an award.

The Commission has occasionally, as in connexion with the Pritchard principle for constructing bombsights, recommended an award where the inventive merit of the contribution consisted mainly of mathematical or theoretical calculations. Claims by employees of Crown contractors have generally been treated on the principle that, if the invention was made in fulfilment of the employee's duty to his employers, he should look to the firm he serves for an ex gratia reward for such services. The Commission was, however, able to treat the status of the claimants in the project known as Pluto and the inventors of the cavity magnetron as substantially the same as that of research workers directly paid by the Crown, since at the time they were lent or seconded to a government department for carrying out the experimental work which led to the invention. An award could be recommended to the inventor of the winged target or pilotless aircraft for towing behind aircraft because the company employing the inventor had waived its claim as patentees against the Crown in favour of the inventor. An award of $£ 2,500$ was recommended in respect of the disk seal triode in spite of some dubiety as to the validity of the claim, in view of some ambiguity in the contract in force and of the merit and extensive usefulness of the technique, particularly in blind firing from ships.

The gratuitous offer to the Crown and its contractors of the free user of a patented invention does not necessarily disqualify the owner of the patent from afterwards qualifying for an ex gratia award; but the Commission has held that surgical or medical 
discoveries, in accordance with the recognized practice of the medical profession, become available for use of the Crown in the same way as for any members of the public. The only award recommended under Head 4 of the Warrant was for a claim in respect of the Sommerfeld track.

\section{THE CATTLE EGRET}

$\mathrm{A}^{\mathrm{x}}$ $\mathrm{N}$ Old World bird which is a constant companion of cows has become established in the United States in the past fifteen years. Unknown there before its first appearance in Florida in 1942, there axe now approximately two thousand birds in that State, according to Alexander Sprunt, jun., of the National Audubon Society (Smithsonian Institution News Release, April 13).

The bird is Bubulcus ibis, the cattle egret, which has been well known for many years in southern Europe, Africa and the Middle East. It is a small white egret with dark-brown feet and yellow legs and bill and is most remarkable for its strange, constant association with cattle. The close proximity to cattle is little short of astonishing. It keeps pace with the animal continually, usually close by the head, but sometimes near the fore or hind feet and occasionally under the abdomen. When an insect is disturbed, the bird darts out, catches it and returns. Now and then it reaches up and takes something from the body of the cow, or its legs. At times, the cow may be seen to push the bird aside with its muzzle, but appears not to object otherwise to the immediate closeness of its satellite.

A peculiar and unexplained characteristic of the bird is its habit of weaving the head and neck from side to side. A bird will suddenly stop feeding, stand perfectly upright, and weave the upper part of the body.

It feeds chiefly on grasshoppers and crickets. This may explain its fondness for cattle, which disturb these insects in the grass while grazing.

How the cattle egret got to the New World, especially the United States, is difficult to explain. It was first observed in British Guiana in 1937, but did not appear in the United States until five years later.

The cattle egret population is concentrated in Florida; but stray specimens have been observed as far north as Maine, and even Newfoundland, and inland to Chicago. Sprunt believes that a few pairs may have been blown over the Atlantic by wind currents.

\section{SEA-BIRDS IN SWEDEN}

TN 1950, regulations came into force in Sweden 1 prohibiting the shooting of sea-birds during the early months of the year. The Swedish Institute of Forest Zoology has now completed investigations to show the effects of these regulations (Bull. Roy. Sch. Forestry, Stockholm, Sweden, No. $22 ; 1956)$. These show that everywhere the eider has increased substantially in numbers, while stocks of the velvet scoter were generally unchanged. This species usually arrives at the breeding places so late that it is scarcely affected by the legal spring shooting. There is, accordingly, a substantial difference between the eider and the velvet scoter in this respect, which supports the assumption that the prohibition of spring shooting - which applied only to the eiderhad a salutary effect on the stock of that species.

The general trend regarding the stocks of Swedish sea birds since the new regulations were introduced has led to the following conclusions.

There is little possibility of distinguishing between male and female birds. Even if differentiation were possible, the male bird in the spring would still be essential for breeding. The risks of wounding birds in the large spring flocks are greater than those in the autumn shooting of migratory birds.

Birds are being shot which have been produced at other places and, at this time of the year, are returning to their production areas. This shooting cannot be motivated by game protection.

Although the amended regulations of 1950 have been of some benefit-indeed, of very appreciable benefit in the case of the eider-further review of the problems of spring shooting is now required.

The question of restricting spring shooting rights to the coastal population should be carefully considered, regardless of whether the shooting is done in public or private waters.

Should this prove impracticable, it is recommended that a general ban on spring shooting be introduced and that the coastal population be compensated by granting them prolonged autumn and winter shooting rights.

Permission might also be given for the limited shooting of male birds in production zones having well-ordered sea-bird protection. A certain amount of spring shooting along the migratory routes beyond the skerries but outside the production zones proper might be permitted as a transitional measure.

\section{EVENING INSTITUTES IN BRITAIN}

$\mathrm{T}$ HE most popular studies pursued at evening institutes are those offering instruction in household handicrafts. More than a quarter of the student body registered, totalling nearly one and threequarter million, are women taking classes in cooking, catering, home-furnishings, needlework and similar subjects for the improvement and decoration of the home.

This significant change in the character of evening classes is revealed by a Ministry of Education survey designed to help local education authorities, principals of institutes and teachers to meet the changing needs of young people and adults for purposeful leisure-time study and occupation*.

The change in public taste, and also in social conditions over a period of twenty years or so, is reflected in subject and attendance figures given. Between 1930 and 1952, the numbers of students studying vocational subjects in evening institutes declined considerably, while the numbers taking non-vocational subjects, such as art, music, handicrafts, dancing, and so on, increased. During this period vocational studies have to a great extent been transferred from evening to day work, largely as a consequence of the increasing readiness of employers to give young people time off during the day for study. The full-time work in technical colleges also increased greatly over the period.

* Evening Institutes. Ministry of Education Pamphlet No. 29. (London: H.M.S.O.) 3s. net. 